\title{
EFFECT OF GROUNDNUT FLOUR SUBSTITUTION ON YIELD, QUALITY AND STORAGE STABILITY OF KILISHI - A NIGERIAN INDIGENOUS DRIED MEAT PRODUCT
}

M gbemere $V N^{*}, A$ kpapunam $M A^{2}$ and $\mathrm{J} O$ I gene ${ }^{3}$

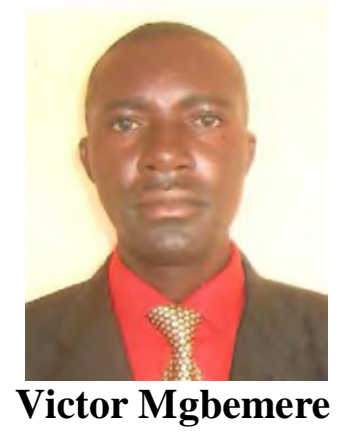

*Corresponding author email: nvmgbemerefrng @yahoo.com

${ }^{1}$ Department of Hospitality \& Catering Management, National Institute for Hospitality and Tourism (NIHOTOUR) P.M.B 3274, Kano, Nigeria

${ }^{2}$ Department of Food Science and Technology, University of Agriculture, P.M.B 2373 Makurdi, Benue Nigeria

${ }^{3}$ Department of Animal Science, Faculty of Agriculture, University of Benin Nigeria 


\section{ABSTRACT}

Kilishi, a traditionally sun-dried roasted meat product usually produced using raw meat, Tunkusa (a locally defatted groundnut cake paste), in combination with spices and condiments in the mix was produced after substitution with conventional defatted groundnut flour. This study was undertaken to establish the potential use of conventional defatted groundnut flour in place of Tunkusa in making a better quality and shelf - stable Kilishi. The yield, quality and storage stability of the product were evaluated using standard assay techniques. Yield was estimated as the ratio of weight of Kilishi over the fresh beef. Quality was measured in terms of proximate composition which included protein, fat, carbohydrate, fibre and ash contents, and the amount of calorie obtained from the Kilishi was calculated based on these constituents. Sensory quality attributes were also measured in terms of colour/appearance, flavour, crispiness, texture and overall acceptability. Microbial counts such as total plate, yeast and mould and coliform were measured. Storage stability was evaluated in terms of thiobarbituric acid (TBA), free fatty acid (FFA) and Peroxide value (PV) values prior and following storage in ambient $\left(25-32^{\circ} \mathrm{C}\right)$ or refrigerator $\left(7 \pm 1^{\circ} \mathrm{C}\right)$ for 12 weeks. Yield of the Kilishi (GFK) produced from conventional defatted groundnut flour ingredients was $87.3 \%$ compared to $83.7 \%$ of traditionally defatted groundnut cake (Tunkusa) Kilishi (TK) (control). The GFK had $12.1 \%$ moisture, $51.8 \%$ protein, $13.4 \%$ fat, $5.1 \%$ ash, $2.8 \%$ crude fibre and $14.8 \%$ carbohydrate compared to TK $11.6 \%, 49.8 \%, 11.4 \%, 5.2 \%, 3.1 \%$, and $18.9 \%$ for these constituents, respectively. GFK also had $387.0 \mathrm{Kcal} / 100 \mathrm{~g}$ energy value compared to 377.4 for TK. Both GFK and TK were highly rated in sensory attributes, however, TK had lesser acceptability. Microbial counts were non detectable in the fresh Kilishi products until week 12 and were within standard safe limits $\left(10^{6} \mathrm{CFU} / \mathrm{g}\right.$ aerobic and $10^{7}$ anaerobic counts) thereafter. At week 12, microbial counts were $2.1 \times 10^{1} \mathrm{CFU} / \mathrm{g}$ bacteria and $3.0 \times 10^{0}$ moulds for GFK stored at ambient $\left(25-32^{\circ} \mathrm{C}\right)$ condition and $4.5 \times 10^{1} \mathrm{CFU} / \mathrm{g}$ bacteria for GFK stored at refrigerator $\left(7 \pm 1^{\circ} \mathrm{C}\right)$ conditions, whereas TK had $1.6 \times 10^{1} \mathrm{CFU} / \mathrm{g}$ bacteria, $1.0 \times 10^{1}$ moulds and $1.1 \times 10^{1}$ CFU/g bacteria. Storage for 12 weeks slightly decreased sensory scores, protein and fat contents and also TBA, FFA, PV but moisture increased slightly. It is possible to produce high quality and yield as well as acceptable and shelf stable Kilishi using conventional defatted groundnut flour. Also GFK Kilishi had better quality attributes when compared with TK, Tunkusa Kilishi.

K ey words: Meat, Tunkusa, Kilishi, Groundnut flour, Quality 


\section{INTRODUCTION}

Kilishi is a traditionally processed, sun-dried, roasted ready-to-eat (RTE) meat product. It is popular especially in Northern Nigeria, Cameroun, Chad, Niger Republic and other countries in the sahelian region of Africa. Kilishi also has been an important export commodity to Saudi Arabia and other Asian countries where it is also widely consumed [1]. Kilishi is brownish in colour, light in weight, rich in protein and contains other vital nutrients [1]. It is mostly consumed as a snack food and as part of a main dish. Its consumption seems to have no age, religious or ethnic barrier.

Processing of Kilishi comprises the use of fresh meat such as beef, lamb, mutton, goat or other essential animal flesh/muscle in combination with Tunkusa (locally defatted groundnut cake paste), spices and condiments in the mix. In the process, fat is trimmed and removed before the meat is sliced / cut into flat thin sheets using a sharp knife. The sheets are spread on raffia mat or wooden tray and sun dried (first stage drying), to reduce the moisture content and condition the meat for ingredient infusion. The pre-dried meat is then coated/infused with the ingredient mix powder (Tunkusa, spices and condiments ground into powder form) slurry and dried again (second stage drying) and finally roasted in a smokeless glowing fire [1]. The resultant Kilishi is often wrapped in a cardboard paper, hawked and sold along the streets, in the filling stations, retail shops, restaurants, hotels, markets and airports.

Use of edible plant material such as flour/protein in comminuted meat product increases yield and lowers cost. Since the cost of conventional animal product is high, plant protein becomes an alternative source. It is cheap and affordable with acceptable organoleptic qualities $[2,3]$. Conventional defatted groundnut flour has been used as a valuable ingredient in many high protein food formulations such as convenience food, snacks soups and beverage [4]. The preparation method of groundnut flour is hygienic, unlike the traditionally defatted groundnut cake paste, Tunkusa, that lacks adequate hygienic practices and, therefore, it is prone to unsafe levels of microorganisms. Also excessive production processes of Tunkusa exposes nutrients especially protein to loss of functionalities, but the utilization of groundnut flour in fabricated foods largely depends on its functional properties $[4,5,6]$.

Nutrients and functional properties would be preserved, and also safer microbiological acceptable levels and better Kilishi would be produced using conventional defatted groundnut flour compared to Tunkusa Kilishi. The objective of this study was to ascertain the effect of conventional defatted groundnut flour substitution on yield, quality and storage stability of Kilishi.

\section{MATERIALSAND METHODS}

\section{M aterials}

Groundnut seed (Arachis hypogeae L.), black pepper (Piper guineas), hot pepper (Capsicium frutecens), sweet pepper (Capsicium anum), Clove (Eugenia carphylatta), ginger (Zingiber officinale), maggi cubes (Bullion), meleguenta (Afromomium 
meleguentg), onion (Allium cepa), table salt and sugar were purchased from Wurukum market in Makurdi, Benue State, Nigeria. Groundnut (Arachis hypoggea) cake paste: Tunkusa and potable water were obtained from kilishi factory in Ekewan Campus University of Benin, Edo State, Nigeria. Beef was purchased from Aduewagh abattoir in Benin City, Edo State, Nigeria.

\section{Preparation of conventional groundnut flour and the defatted flour}

Clean $5 \mathrm{~kg}$ groundnut seeds were mildly roasted in an air oven at $48 \pm 2^{\circ} \mathrm{C}$, decuticled by hand abrasion, winnowed and the hulls removed. The kernels were oven dried at $55 \pm 2{ }^{\circ} \mathrm{C}$ for 5 hours and milled into flour with a kitchen blender (Philip, HR 1702), sieved to a particle size of $225 \mathrm{~m}$, spread on a tray $(45 \times 45 \mathrm{~cm})$ at a loading depth of $10 \mathrm{~mm}$ and toasted in the oven at $105 \pm 1{ }^{\circ} \mathrm{C}$. The resultant flour was defatted by placing the flour in a muslin cloth, screw pressed to maximum pressure $(20 \mathrm{psi})$, and oil extracted until a fat content of $19.8 \%$ was attained. The defatted flour was toasted in an oven at $105 \pm 1^{\circ} \mathrm{C}$, packaged in cellophane bags $20 \mathrm{~m}$ thick and stored in a refrigerated at $7 \pm 1^{\circ} \mathrm{C}[7,8]$.

\section{Preparation of ingredient powder mix}

Clean dry spice or condiment $(100 \mathrm{~g}$ of each) was dried further in an air oven at $40 \pm 2{ }^{\circ} \mathrm{C}$ for six hours and ground using a kitchen blender. The resultant feed/powder was sieved with standard mesh and the average particle size was $225 \mathrm{~m}$. One $\mathrm{kg}$ of fresh onion was sliced and spread on a tray $(45 \times 45 \mathrm{~cm})$ to a loading depth of $50 \mathrm{~mm}$ and dried at $40 \pm 2^{\circ} \mathrm{C}$ for 12 hours, ground, sieved, proportioned and blended into the ingredients mix [9].

\section{Production, packaging and storage of the kilishi}

Four and half (4.5) $\mathrm{kg}$ of fresh beef was trimmed and the fat was removed. The resultant lean beef $(4.3 \mathrm{~kg})$ was sliced into thin sheets of $0.15-0.20 \mathrm{~cm}$ thick, arranged on a cleaned stainless tray $(45 \times 100 \mathrm{~cm})$ to a loading depth of $0.15-0.20 \mathrm{~cm}$, dried in an air oven $50 \pm 1^{\circ} \mathrm{C}$ for 4 hours to $25.2 \pm 0.3 \%$ moisture content. Total $2.4 \mathrm{~kg}$ of the ingredient powder mix including $1.84 \mathrm{~kg}$ of defatted groundnut flour or Tunkusa was weighed using a digital scale (FP-300 Fisher Sci. Edu. USA) into a clean plastic bowl (45cm diameter $\times 20 \mathrm{~cm}$ depth) and mixed with $5.6 \mathrm{~L}$ of boiled, cooled water at $50 \pm 1^{\circ} \mathrm{C}$ to form a slurry. About $2.39 \mathrm{~kg}$ of the pre-dried sliced beef was immersed in the slurry for 30 minutes and the beef was infused. The infused beef $(10.25 \mathrm{~kg})$ was arranged on the cleaned tray $(45 \times 100 \mathrm{~cm})$ to a loading depth of $0.4-0.55 \mathrm{~cm}$ and dried in the oven at $50 \pm 1^{\circ} \mathrm{C}$ for 4 hours, arranged on the tray and placed on an oven glowing with smokeless charcoal fire at $250 \pm 1^{\circ} \mathrm{C}$ and roasted for 5 minutes. The resultant Kilishi was cooled under the revolving ceiling fan and weighed. Tunkusa Kilishi (TK) (control) and conventional defatted groundnut flour Kilishi (GFK) were packaged $100 \mathrm{~g}$ per pack, respectively using sterile $20 \mathrm{~m}$ thickness cellophane bags and vacuum sealed (KOCH Ultravac UV 250 equip, Inc, USA) and placed into a plastic container $\left(20 \mathrm{~cm}\right.$ diameter $\times 30 \mathrm{~cm}$ depth) and stored at ambient $\left(25-32^{\circ} \mathrm{C}\right)$ or refrigerator $\left(7 \pm 1^{\circ} \mathrm{C}\right)$ for 12 weeks.

Determination of yield, proximate composition and energy value

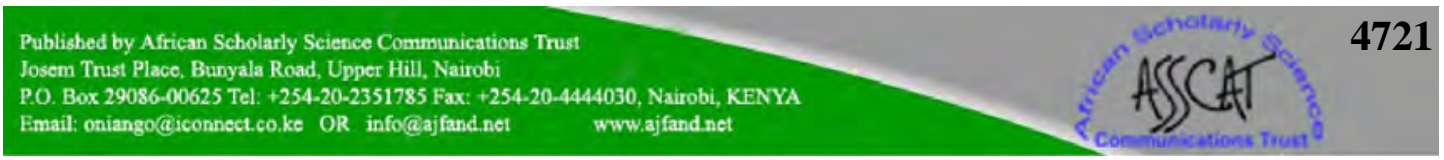


Moisture content was determined using moisture analyzer (MB 35 Halogen OHAUS) at $105^{\circ} \mathrm{C}$. Five (5) grams Kilishi sample was placed into clean dry analyzer cabinet dish. The heater was turned on and the sample was heated, the moisture content was attained and heating stopped automatically. The actual yield was expressed as the ratio of final weight of Kilishi to the fresh sliced beef sheets [10]. Protein (Nx6.25), fat, ash and crude fibre contents of the Kilishi were determined according to AOAC [11]. Carbohydrate was calculated by difference [12]. Energy value (Kcal/100g) was evaluated thus: ( 4 x Carbohydrate +4 x Protein +9 x Fat) [13]

Determination of peroxide value (PV), thiobarbituric acid (TBA), free fatty acid (FFA) and hydrogen ion concentration $(\mathrm{pH})$ value

Peroxide value: $5 \mathrm{~g}$ Kilishi sample was weighed into a $250 \mathrm{ml}$ Erlenmeyer flask. Exactly $30 \mathrm{ml}$ of acetic acid-chloroform (2:1) solution was added and swirled to dissolve. Exactly $5 \mathrm{ml}$ of saturated solution of potassium iodide was added and allowed to stand for one minute with occasional shaking. The mixture was added to $30 \mathrm{ml}$ of distilled water and titrated with $0.1 \mathrm{ml}$ sodium thiosulphate with vigorous shaking until the yellow colour nearly faded away. Then $0.5 \mathrm{ml}$ of $1 \%$ starch solution was added and titration continued until the blue colour first disappeared. A blank consisting of distilled water in place of the extract was also prepared and titrated. From these, the PV was calculated [11].

For the thiobarbituric acid: $10 \mathrm{~g}$ of Kilishi sample was blended in a kitchen blender and transferred into a clean-dried conical flask. To it $50 \mathrm{ml}$ distilled water was added, mixed thoroughly and filtered using filter paper (whatman). $5 \mathrm{ml}$ of the extract was mixed in a test tube with $5 \mathrm{ml}$ of $0.2 \mathrm{~g}$ 2-thiobarbituric acid (Sigma-Aldrich Inc.) in $100 \mathrm{ml}$ of distilled water. A blank consisting of $5 \mathrm{ml}$ of the 2-thiobarbituric acid dissolved with $5 \mathrm{ml}$ distilled water in a test tube was prepared. Both the sample and the blank were stoppered with aluminum foil and allowed to stay at ambient temperature $25-32^{\circ} \mathrm{C}$ for 24 hours. The absorbance was measured at $538 \mathrm{~nm}$ using a spectrophotometer (Spectronic 20) and converted to TBA number [14].

For free fatty acid: neutral solvent was prepared by mixing $25 \mathrm{ml}$ of diethyl ether with $25 \mathrm{ml}$ ethanol plus $1 \mathrm{ml}$ of $1 \%$ phenolphthalein indicator and carefully neutralized with $0.1 \mathrm{M}$ sodium hydroxide solution. Exactly $5 \mathrm{~g}$ Kilishi sample was dissolved in the neutral solvent and titrated against aqueous $0.1 \mathrm{M}$ solution of sodium hydroxide with shaking until the pink colour that lasted about $15 \mathrm{sec}$. was obtained [15].

Hydrogen ion concentration $(\mathrm{pH})$ value was determined by blending $5 \mathrm{~g}$ Kilishi sample using kitchen blender (Philips HR, 1702). This was transferred into a 100ml beaker and mixed with deionized water. The mixture was filtered and the $\mathrm{pH}$ measured using single electrode digital $\mathrm{pH}$ meter (Philip), [16]. All determinations were in triplicate.

\section{Microbial evaluation}

Glass wares were aseptically prepared. About $1 \mathrm{~g}$ Kilishi was randomly selected from each Kilishi samples and blended thoroughly with $9 \mathrm{ml}$ sterile distilled water in a test tube. Subsequently, serial dilutions were prepared appropriately. About $1 \mathrm{ml}$ of each diluent was then aseptically transferred into coded sterile Petri dishes. For total plate 
counts: $7 \mathrm{~g}$ of nutrient agar (Anteg. Diagnostic $\mathrm{T}^{\mathrm{m}} \mathrm{U} . \mathrm{K}$ ), and for yeast and mould counts, 9.75g potatoes dextrose agar (PDA) (Int. Diagnostic group Plc ideg) was dissolved in $250 \mathrm{ml}$ of distilled water and sterilized in an autoclave at $121^{\circ} \mathrm{C}$ for 20 minutes and allowed to cool to $40-44^{\circ} \mathrm{C}$ before $10 \mathrm{ml}$ was poured to each of the coded Petri dishes containing the diluents, respectively. These were swirled gently and allowed to solidify. The plates were inverted and incubated, for total plate counts at $32^{\circ} \mathrm{C}$ for $44-48$ hours and for yeast and mould counts at $36^{\circ} \mathrm{C}$ for four days in a Gallenkamp incubator. After incubation, counts were determined using digital colony counter (JP secter S.A). The total bacteria counts were reported as CFU/g. For coliform counts: McConkey media was used [17].

\section{Sensory evaluation}

Kilishi sample was placed in a coded dish and presented to a 25 -member panel consisting of 10 who are familiar with Kilishi and 15 who are not familiar with Kilishi. The panel evaluated the Kilishi based on colour, flavour, texture, crispiness and overall acceptability using a 9-point hedonic scale [18].

\section{Analysis of data}

The mean scores obtained from the yield, proximate composition, sensory evaluation and microbiological data were tested for significant difference at $5 \%$ probability level using analysis of variance (ANOVA). Turkey's least significant difference (LSD) test was used to separate means with significant differences [19].

\section{RESULTS}

\section{Ingredient proportion}

Table 1 shows the proportion of ingredients/raw materials used in the Kilishi processing. Proportion of the ingredients ranged from $1.3 \mathrm{~g}(0.13 \%)$ in clove to $459.14 \mathrm{~g}$ (45.9\%) in Tunkusa or conventional defatted groundnut flour.

\section{Proximate composition (dry weight basis), yield and energy value of the Kilishi products}

Table 2 shows proximate composition, yield and energy value of Tunkusa (TK) (control) and conventional defatted groundnut flour (GFK) Kilishi. The Kilishi products had low moisture contents which ranged from $11.6 \%$ in TK to $12.1 \%$ in GFK. Both GFK and TK had high protein contents with GFK containing higher protein content of $51.4 \%$ compared to TK $49.8 \%$. For fat content, TK had $11.4 \%$ which was significantly ( $\mathrm{P} ₫ 0.05$ ) lower when compared to $13.4 \%$ in GFK. Ash contents of the Kilishi products were high. TK had slightly higher ash content of 5.2\% than $5.1 \%$ ash content of GFK. The crude fibre contents were low. It ranged from $2.8 \%$ in GFK to $3.1 \%$ in TK. Carbohydrate contents ranged from $14.8 \%$ in GFK to $18.9 \%$ in TK. The carbohydrate contents differed significantly (P $₫ 0.05$ ).

Table 2 also shows the yield of Tunkusa (TK) (control) and conventional defatted groundnut flour (GFK) Kilishi. The yield ranged from $83.7 \%-87.3 \%$. Yield of GFK Kilishi was significantly (P $₫ .05$ ) higher than yield of TK. Also Table 2 shows the energy value of TK and GFK Kilishi. Groundnut flour kilishi (GFK) had higher 
energy value of $387.0 \mathrm{Kcal} / 100 \mathrm{~g}$ than $377.4 \mathrm{Kcal} / 100 \mathrm{~g}$ of TK Kilishi. The energy value also differed significantly (P $₫ 0.05$ ).

Sensory scores of the Kilishi product

Table 3 shows the mean sensory scores of Tunkusa Kilishi (TK) (control) and conventional defatted groundnut flour Kilishi (GFK). Although there were significant differences ( $\mathrm{P} \$ 0.05$ ) between GFK and TK in the sensory attributes, both products had very high scores in all the attributes. The GFK (groundnut flour Kilishi) (GFK) had scores higher than TK in appearance, texture, flavour, crispiness and overall acceptability.

Effect of storage at ambient $\left(25-32^{\circ} \mathrm{C}\right)$ refrigerator $\left(7 \pm 1^{\circ} \mathrm{C}\right)$ on sensory score of the Kilishi products

Table 4 shows the effect of storage at ambient $\left(25-32^{\circ} \mathrm{C}\right)$ and refrigerator $\left(7 \pm 1^{\circ} \mathrm{C}\right)$ on sensory score of the Kilishi. During storage, the mean sensory scores of both Kilishi products maintained high ratings in all the attributes. However, Tunkusa Kilishi (TK) (control) had slightly lower rating than groundnut flour Kilishi (GFK).

Effect of storage on hydrogen ion concentration value $(\mathrm{pH})$, free fatty acid (FFA), thiobarbituric acid (TBA) and peroxide value (PV) of the Kilishi products Table 5 shows the effect of storage on hydrogen ion concentration $(\mathrm{pH})$ value of the Kilishi products. The $\mathrm{pH}$ values slightly increased more in the Kilishi stored in the refrigerator $\left(7 \pm 1^{\circ} \mathrm{C}\right)$ temperature than Kilishi stored at ambient temperature. Hydrogen ion concentration $(\mathrm{pH})$ values for Tunkusa Kilishi (TK) (control) ranged from 6.09 to 6.64 at ambient $\left(25-32^{\circ} \mathrm{C}\right)$ and 6.09 to 6.28 at refrigerator $\left(7 \pm 1^{\circ} \mathrm{C}\right)$ temperatures storage period (week one to week 12). Similarly, GFK had a pH range of 6.18 to 6.28 at ambient $\left(25-32^{\circ} \mathrm{C}\right)$ and 6.18 to 6.30 at refrigerator $\left(7 \pm 1^{\circ} \mathrm{C}\right)$ temperatures storage for a period of one to 12 weeks.

Figure 1 shows the effect of storage on free fatty acid (FFA). The free fatty acid values were relatively reduced in the Kilishi products stored in refrigerator and at ambient temperatures over the storage period. In the first week, both GFK and TK Kilishi (control) had FFA 1.86 and $1.89 \%$ oleic acid, respectively. However, FFA of TK Kilishi reduced to 1.64 and $1.61 \%$ oleic acid while FFA of GFK reduced to 1.72 at ambient $\left(25-32^{\circ} \mathrm{C}\right)$ temperature and 1.69 (\% oleic acid) at refrigerator $\left(7 \pm 1^{\circ} \mathrm{C}\right)$ temperature in week twelve during storage period. 


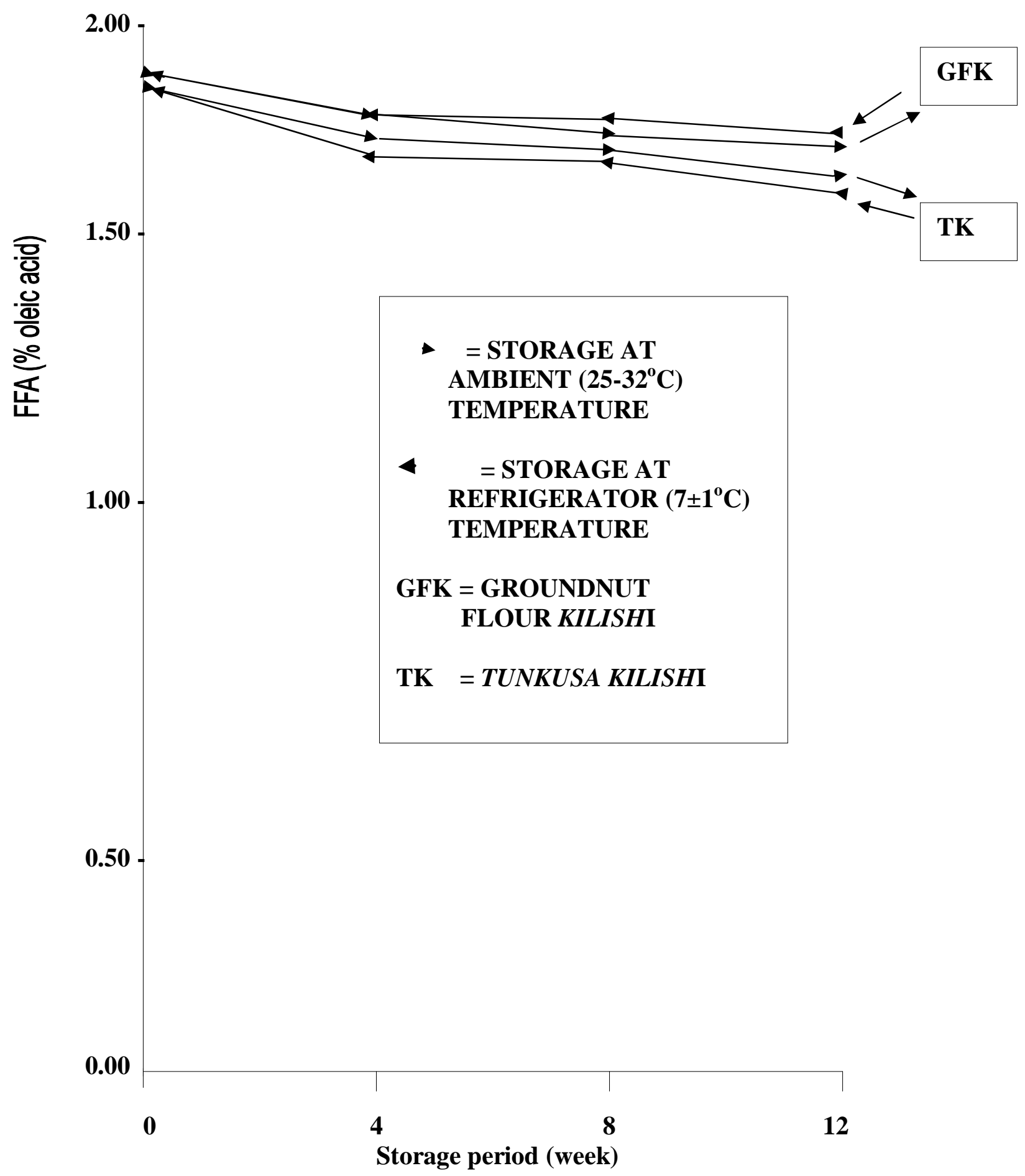

Figure 1: Effect of storage at ambient $\left(25-32^{\circ} \mathrm{C}\right)$ and refrigerator $\left(7 \pm 1^{\circ} \mathrm{C}\right)$ temperatures on free fatty acid (FFA) of (GFK) groundnut flour and (TK ) tunkusa kilishi 


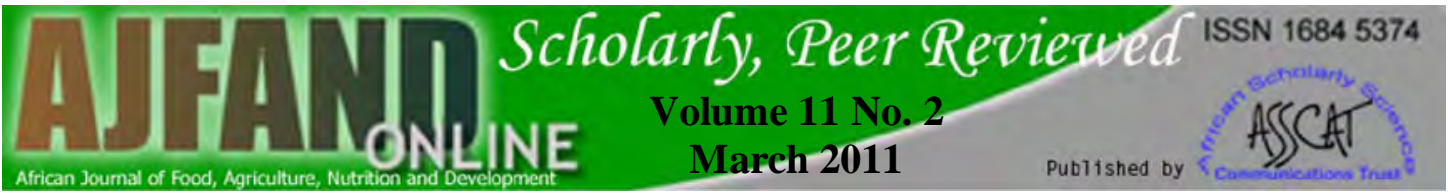

Figure 2 shows the effect of storage on thiobarbituric acid (TBA) of the Kilishi products. TBA values were higher at week zero but lowered subsequently during storage. Groundnut flour Kilishi (GFK) had higher TBA values than Tunkusa (TK) (control). For samples stored at ambient, the TBA value ranged from 1.58 to $1.45 \mathrm{mg}$ malonaldehyde/Kg sample in GFK and 1.56 to $1.40 \mathrm{mg}$ malonaldehyde $/ \mathrm{Kg}$ sample in TK Kilishi while refrigerated samples values ranged from 1.58 to 1.41 in GFK and 1.56 to $1.39 \mathrm{mg}$ malonaldehyde/Kg sample in TK Kilishi. Kilishi samples stored at refrigerator $\left(7 \pm 1^{\circ} \mathrm{C}\right)$ had slightly lower changes in TBA than samples stored at ambient $\left(25-32^{\circ} \mathrm{C}\right)$ temperature.

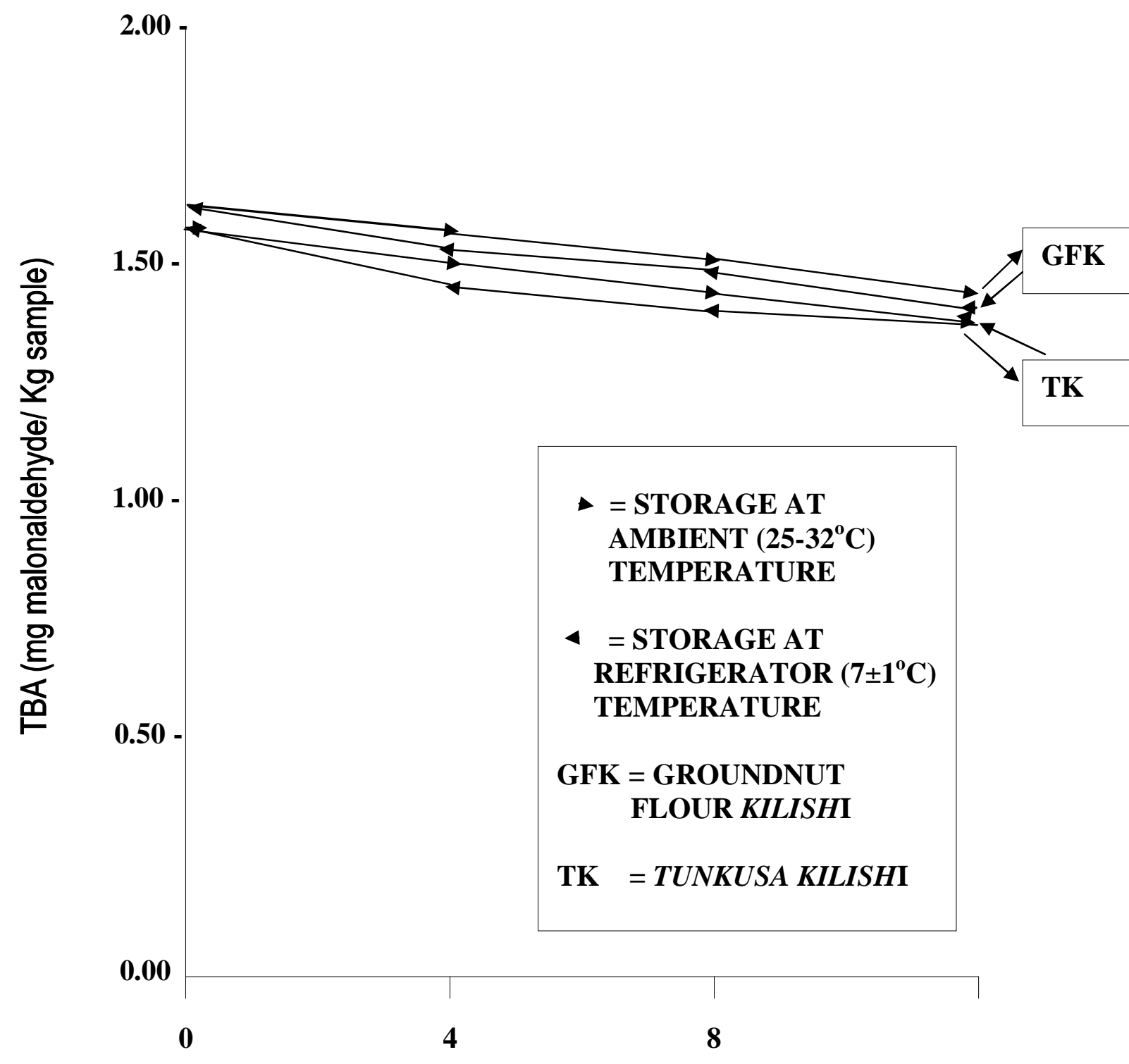

12

Storage period (week)

Figure 2: Effect of storage at ambient $\left(25-32^{\circ} \mathrm{C}\right)$ and refrigerator $\left(7 \pm 1^{\circ} \mathrm{C}\right)$ temperatures on thiobarbituric (TBA) of (GFK) groundnut flour and (TK ) tunkusa kilishi 
Figure 3 shows the effect of storage on peroxide value (PV) of the Kilishi products. Peroxide values (PV) were higher at week zero and decreased during storage. The PV values ranged from 1.52 to $1.72 \mathrm{meq} / \mathrm{Kg}$ sample across Kilishi stored at both ambient and refrigerator temperatures. Groundnut flour Kilishi (GFK) had lower PV ranging from 1.73 to $1.64 \mathrm{meq} / \mathrm{Kg}$ sample while $\mathrm{TK}$ (control) Kilishi had PV ranging from 1.70 to $1.52 \mathrm{meq} / \mathrm{Kg}$ sample. Also, Kilishi samples stored at refrigerator $\left(7 \pm 1^{\circ} \mathrm{C}\right)$ temperature had slightly lower changes in PV than Kilishi stored at ambient $\left(25-32^{\circ} \mathrm{C}\right)$ temperature.

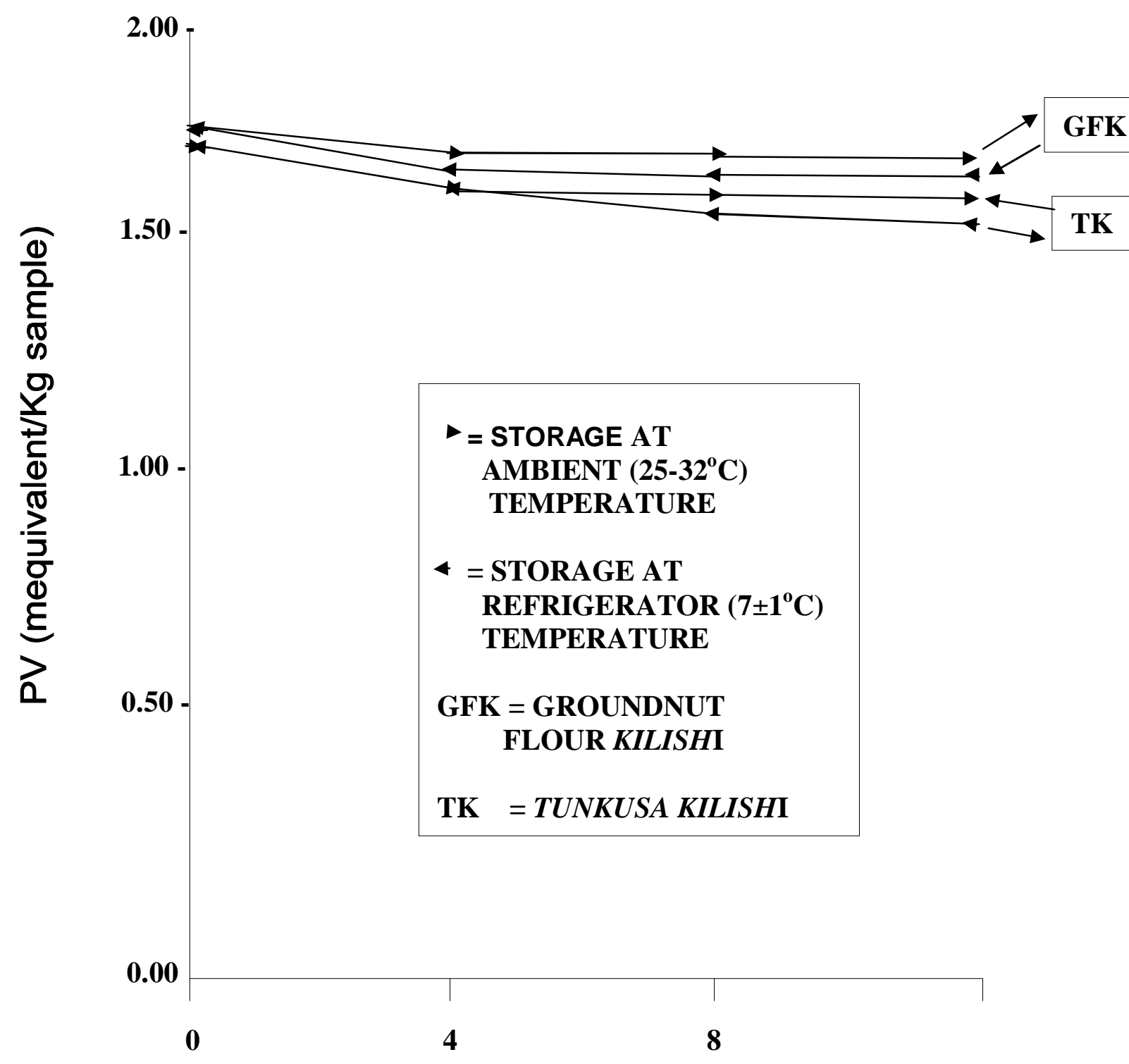

12

Storage period (week)

Figure 3: Effect of storage at ambient $\left(25-32^{\circ} \mathrm{C}\right)$ and refrigerator $\left(7 \pm 1^{\circ} \mathrm{C}\right)$ temperatures on peroxide value (PV) of (GFK) groundnut flour and (TK ) tunkusa kilishi 
Effect of storage at ambient $\left(25-32^{\circ} \mathrm{C}\right)$ refrigerator $\left(7 \pm 1^{\circ} \mathrm{C}\right)$ on microbial load of Kilishi

The microbial counts in both GFK and TK (control) during storage were non detectable (ND) until week twelve. Tunkusa Kilishi (TK) stored at ambient had bacterial counts of $1.6 \times 10^{1} \mathrm{CFU} / \mathrm{g}$ and mould counts $1.0 \times 10^{1} \mathrm{CFU} / \mathrm{g}$ while the samples stored at refrigerator had bacterial counts $1.1 \times 10^{1} \mathrm{CFU} / \mathrm{g}$. Similarly, GFK stored at ambient had bacterial counts $2.1 \times 10^{1} \mathrm{CFU} / \mathrm{g}$ and mould counts $3.0 \times 10^{1}$. Groundnut flour Kilishi (GFK) samples stored at refrigerator had bacterial counts of $4.5 \times 10^{1} \mathrm{CFU} / \mathrm{g}$. At week twelve, the microbial counts were higher in GFK than in TK (control).

\section{DISCUSSION}

\section{Ingredient proportion}

The proportion of the ingredient probably indicates their essentiality in Kilishi production. Ingredients with high proportions might be major contributors to the physio-chemical properties of the processed Kilishi product. Earlier studies on Kilishi indicated that high proportion of Tunkusa (traditionally defatted groundnut cake) used in Kilishi processing contributed significantly to the physio-chemical properties of the Kilishi product [20]. In the same vein, the conventionally defatted groundnut flour would greatly influence the overall characteristic of its Kilishi.

\section{Proximate composition (dry weight basis), yield and energy value of the Kilishi products}

The low moisture content of the Kilishi indicates that the products were well dried. If the products are packaged, at this moisture level with materials that are low in moisture permeability, the products would be at water activity level that may protect it from microorganism spoilage. Both GFK and TK had high levels of protein contents. However, GFK had higher protein content $51.4 \%$ compared to TK (control) $49.8 \%$. If both products were dried to the same level of moisture content, GFK might have had much more protein than TK. A significant quantity of protein might have been lost from Tunkusa due to its production process, which involved repeatedly hand squeezing of the groundnut cake paste and extraction of the oil with warm water. The higher level of protein obtained in GFK Kilishi suggests that conventional defatted groundnut flour would be a potential replacement of Tunkusa for a protein rich Kilishi. Fat content of TK, $11.4 \%$ was significantly (P $₫ 0.05$ ) lower when compared to $13.4 \%$ in GFK. The reason for lower fat content in TK was because the Tunkusa used was defatted to a lower fat content $(12.2 \%)$ compared to $19.8 \%$ in conventional defatted groundnut flour. Lower fat content in TK might have contributed to lesser rating of TK in flavour attribute since fat usually influences flavour of meat products. High ash contents recorded in the Kilishi products particularly in TK Kilishi (control) might be due to contamination of Tunkusa by foreign bodies such as dirt. Contamination resulting from production process of Tunkusa might influence the mineral content of traditional processed meat such as Kilishi [21]. Crude fibre as well as carbohydrate might be contributed by flour, spices and condiment such as ginger, onion and pepper used in the Kilishi production [22]. The higher value of carbohydrate in TK might be because the carbohydrate was calculated by difference (the sum total of the other constituents subtracted from 100). The result of proximate 
composition in this study indicated that GFK is a potential replacement for protein rich and other essential nutrients in Kilishi product.

The yield $(87.3 \%$ ) of the GFK Kilishi was significantly (P $\$ 0.05$ ) higher than TK $(83.7 \%)$. This might be because the conventional defatted groundnut flour bound more of the ingredients. Yield (87\%) has been recorded in Tunkusa Kilishi produced with sodium tripolyphosphate (STPP). The STPP was meant to improve the yield of Kilishi [12]. Production process of Tunkusa could affect its functionality adversely including the capacity to bind ingredients. This result on yield suggests that conventional defatted groundnut flour could improve yield in Kilishi.

Calculated energy value of $387.0 \mathrm{Kcal} / 100 \mathrm{~g}$ in GFK was higher than $377.4 \mathrm{Kcal} / 100 \mathrm{~g}$ in TK K ilishi. This energy value differed slightly from $510 \mathrm{Kcal} / 125 \mathrm{~g}$ energy value for Kilishi product previously reported [23]. The difference might be from the constituents such as protein, fat and carbohydrate from which the energy value was evaluated. This high energy values apparently suggest that both GFK and TK Kilishi products are potential sources of vital energy for human consumption.

Sensory scores of the kilishi product

Table 3, shows the mean sensory scores of Tunkusa Kilishi (TK) (control) and conventional defatted groundnut flour Kilishi (GFK). Although there were significant differences ( $\mathrm{P}$ \$.05) between GFK and TK in the sensory attributes, both products had very high scores in all the attributes evaluated. Groundnut flour Kilishi (GFK) was more highly scored than TK in all the attributes (appearance, texture, flavour, crispiness and overall acceptability). Due to the manner of production process of Tunkusa, oxidation might set in and affect adversely the flavour of its product. The overall acceptability of the Kilishi products might be due to flavour and other attributes contributed by meat, oil, protein, spices and flavonoids which influence palatability and acceptability of products. The result of this study suggests consumers' greater preference of GFK to TK. During storage the mean sensory scores (Table 4) of the Kilishi products maintained high ratings. This suggests that storage for 12 weeks did not adversely affect the products.

E ffect of storage on hydrogen ion concentration $(\mathrm{pH})$ value, free fatty acid (FFA) thiobarbituric acid (TBA) and peroxide value (PV) of the Kilishi products

Hydrogen ion concentration $(\mathrm{pH})$ values (Table 5) slightly increased more in the Kilishi stored in the refrigerator than Kilishi stored at ambient temperature probably due to protein degrading microorganisms such as Pseudomonas that predominates at low temperature. Proteolytic microorganism aided by lactic acid bacteria could cause sourness in meat and meat products [24]. Also the result of this study suggests some degree of stability of the Kilishi products.

The FFA values (Figure 1) were relatively reduced in the Kilishi products stored in refrigerator and at ambient over the storage period. This result differs from high FFA value in Kilishi produced with undefatted groundnut cake paste, Tunkusa [25]. The reduced FFA values in this study might be because both the Tunkusa and groundnut flour used in the production of Kilishi were defatted. Also this result suggests high oxidative stability of these Kilishi products.

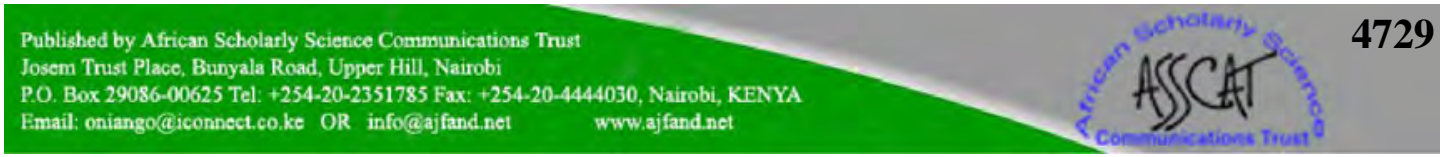


TBA values also were higher at week zero probably because of high rate of oxidation stimulated by the method of Kilishi such as heat drying. Groundnut flour Kilishi (GFK) had higher TBA than TK. Higher fat level recorded in GFK than TK Kilishi could provide more substrate for lipid oxidation. Thiobarbituric acid (TBA), however, declined progressively at subsequent storage weeks. This might be that the spices and condiments used in the production provided antioxidant effect on the products. Kilishi products stored in the refrigerator $\left(7 \pm 1^{\circ} \mathrm{C}\right)$ had lower TBA values compared to products store at ambient $\left(25-32^{\circ} \mathrm{C}\right)$. This might be because low temperature slowed down lipid oxidation. This trend in TBA agrees with higher TBA values that declined during storage of Kilishi [26]. Thiobarbituric acid (TBA) values, highest ranges (1.58 to $1.45 \mathrm{mg}$ malonaldehyde/ $\mathrm{Kg}$ sample) obtained before and after storage in this study were within the threshold of $1.8 \mathrm{mg}$ malonaldehyde $/ \mathrm{Kg}$ sample suggested in previous reports [27]. This suggests stability of the Kilishi products.

PV values were higher in week zero and decreased during storage. The low moisture contents of the Kilishi products might be responsible for the decreased PV values. Water inhibits incipient oxidation of lipid but promote secondary reaction of lipid degradation products with protein at increasing water activity (aw) [28]. The PV values range of 1.52 to $1.72 \mathrm{meq} / \mathrm{Kg}$ sample across Kilishi stored both at ambient and refrigerator is within the acceptable limits of 10.0 to $20 \mathrm{meq} / \mathrm{Kgsample}$ [29].

\section{Effect of storage at ambient $\left(25-32^{\circ} \mathrm{C}\right)$ refrigerator $\left(7 \pm 1^{\circ} \mathrm{C}\right)$ on microbial load of Kilishi products}

The microbial counts in both GFK and TK during storage were non detectable (ND) until week 12. However, the microbial counts observed at week 12 storage periods might be due to post processing contamination probably from the air in the environment and other medium during packaging. The microorganisms probably succeeded the hurdle of non-access to moisture and / or other growth factors. The highest microbial counts $\left(4.5 \times 10^{1} \mathrm{CFU} / \mathrm{g}\right)$ obtained in this study were lower than the limit $\left(10^{6} \mathrm{CFU} / \mathrm{g}\right.$ counts for aerobic and $10^{7} \mathrm{CFU} / \mathrm{g}$ count for anaerobic microorganisms) suggested for dry meat products [29, 30].

\section{CONCLUSION}

The result of this study has shown that conventional defatted groundnut flour base Kilishi (GFK) can enhance the yield and quality of Kilishi products. Conventional defatted groundnut flour base Kilishi had more protein and yield than Tunkusa Kilishi (TK) (control). Even though both Kilishi products compared well in organoleptic qualities, GFK was more acceptable than TK. Also storage indices were better in the conventional defatted groundnut flour base Kilishi than Tunkusa Kilishi (TK) (control). These appreciable attributes make the groundnut flour a potential for Kilishi production. Further study on Kilishi processing using other locally available edible beans would help to make Kilishi product abundant for consumption. 
Table 1:Ingredient proportion for the kilishi production

English/scientific/local name of spices and condiments

Proportion

(g)

Black pepper, Piper guineese (masoro)

2.5

Hot Pepper, Capsicium frutecens (Barkono)

Sweet Pepper, Capsicium anum (Tattashe)

11.0

Clove, Eugenia carphylatta (kanufari)

Ginger, Zingiber officinale

Groundnut Paste, Arachis hypogeae (Tunkusa)/

Groundnut flour, Arachis hypogeae

Maggi cubes (Bullion)

Onion Alluim cepa (Albasa)

Table salt (Sodium chloride)

Sugar (Sucrose)

10.3

Meleguenta Afromomum meleguenta (Chitta miya)

Water

400.0

Total

1000 


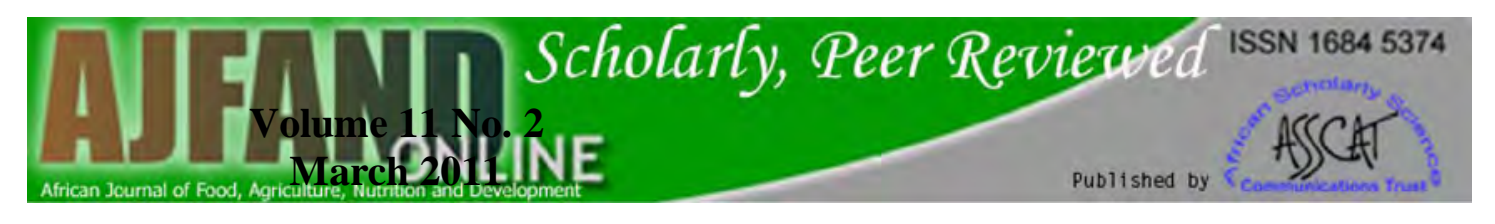

Table 2: Proximate composition (\%) yield (\%) and energy value of the kilishi products (dry weight basis

\begin{tabular}{|c|c|c|c|c|c|c|c|c|}
\hline $\begin{array}{l}\text { Kilishi } \\
\text { sample }\end{array}$ & M oisture & Protein & Fat & Ash & $\begin{array}{l}\text { Crude } \\
\text { fibre }\end{array}$ & $\begin{array}{l}\text { Carbo- } \\
\text { hydrate* }\end{array}$ & $\begin{array}{r}\text { Y ield } \\
(\%)\end{array}$ & $\begin{array}{l}\text { Energy } \\
\text { Value }\end{array}$ \\
\hline & & & & & & & & (K cal/100g) \\
\hline TK & $11.6^{\mathrm{a}} \pm 0.4$ & $49.8^{\mathrm{a}} \pm 0.2$ & $11.4^{\mathrm{b}} \pm 0.3$ & $5.2^{\mathrm{a}} \pm 0.2$ & $3.1^{\mathrm{a}} \pm 0.2$ & $18.9^{\mathrm{b}} \pm 0.3$ & $83.7^{\mathrm{b}} \pm 0.4$ & $377.4^{\mathrm{b}} \pm 0.4$ \\
\hline GFK & $12.1^{\mathrm{a}} \pm 0.3$ & $51.4^{\mathrm{a}} \pm 0.3$ & $13.4^{\mathrm{a}} \pm 0.2$ & $5.1^{\mathrm{a}} \pm 0.3$ & $2.8^{\mathrm{a}} \pm 0.3$ & $14.8^{\mathrm{a}} \pm 0.4$ & $87.3^{\mathrm{a}} \pm 0.3$ & $387.0^{\mathrm{a}} \pm 0.2$ \\
\hline
\end{tabular}

(a) Values are means \pm standard deviations of triplicate determinations;

(b) Values not followed by the same superscript on the same column are significantly different (P $₫$ (0).05).

\section{KEY $:$ GFK $=$ Groundnut flour kilishi}

TK =T unkusa kilishi (Control)

* = By difference

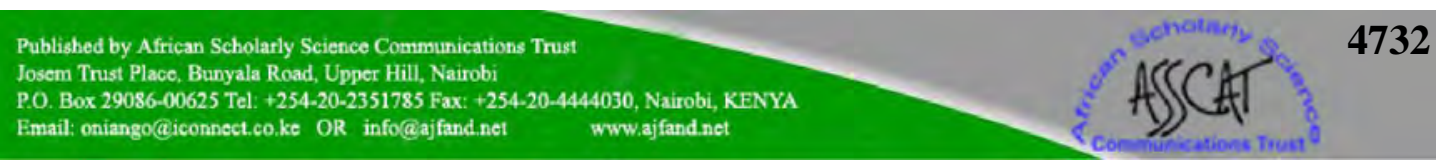




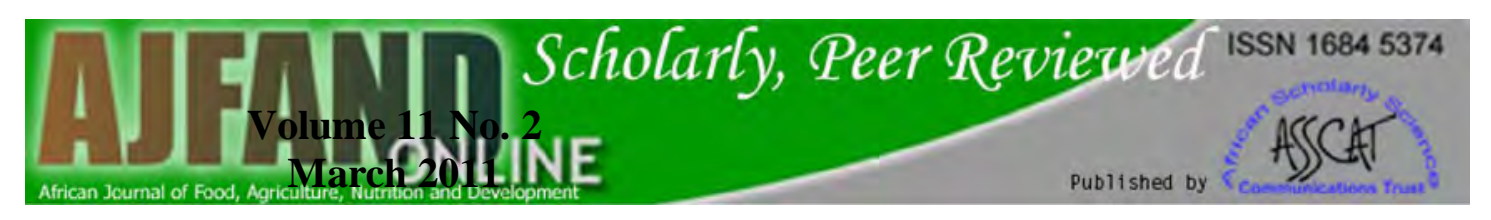

Table 3: M ean sensory scores of the kilishi products

\begin{tabular}{|c|c|c|c|c|c|}
\hline Kilishi sample & Appearance & Texture & Crispiness & Flavour & Overall \\
\hline & & & & & acceptability \\
\hline TK & $6.1^{\mathrm{b}}$ & $6.4^{\mathrm{b}}$ & $6.7^{\mathrm{b}}$ & $6.1^{\mathrm{b}}$ & $6.3^{\mathrm{b}}$ \\
\hline
\end{tabular}

(a) Values are means of triplicate determination;

(b) Values not followed by the same superscript on the same column are significantly different (P $₫$ (0.05)

KEY : TK = Tunkusa Kilishi (Control)

GFK = Groundnut flour Kilishi

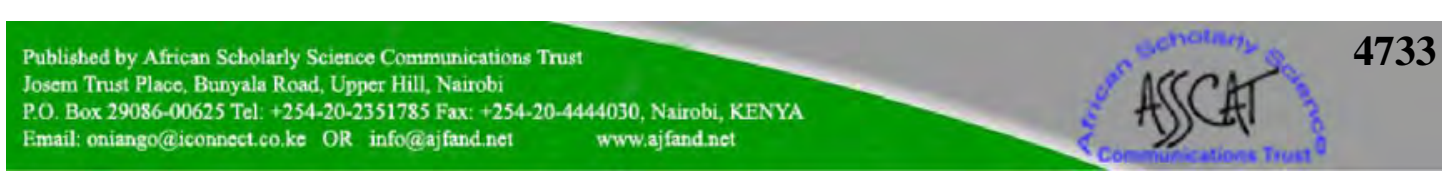




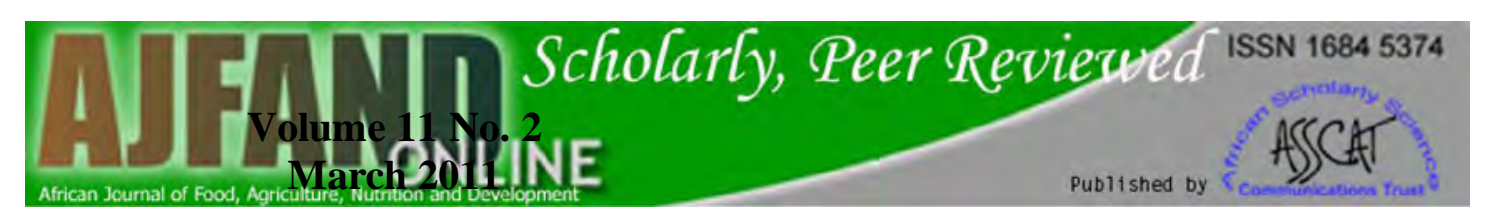

Table 4: $\mathrm{M}$ ean sensory scores of kilishi stored at ambient $\left(25-32^{\circ} \mathrm{C}\right)$ and refrigerator $\left(7 \pm 1^{\circ} \mathrm{C}\right)$

\begin{tabular}{|c|c|c|c|c|c|c|c|c|c|c|c|}
\hline \multirow[b]{2}{*}{$\begin{array}{l}\text { Kilishi } \\
\text { Sample }\end{array}$} & \multirow[b]{2}{*}{$\begin{array}{l}\text { Storage } \\
\text { period } \\
\text { (W eek) }\end{array}$} & \multicolumn{5}{|c|}{$\begin{array}{c}\text { Ambient }\left(25-32^{\circ} \mathrm{C}\right) \\
\text { Attributes }\end{array}$} & \multicolumn{5}{|c|}{$\begin{array}{c}\text { Refrigerator }\left(7 \pm 1^{\circ} \mathrm{C}\right) \\
\text { Attributes }\end{array}$} \\
\hline & & $\begin{array}{l}\text { Appea- } \\
\text { rance }\end{array}$ & Texture & $\begin{array}{l}\text { Crispi- } \\
\text { ness }\end{array}$ & Flavour & $\begin{array}{l}\text { Overall- } \\
\text { accept- } \\
\text { ability }\end{array}$ & $\begin{array}{l}\text { Appea- } \\
\text { rance }\end{array}$ & Texture & $\begin{array}{l}\text { Crispi- } \\
\text { ness }\end{array}$ & Flavour & $\begin{array}{l}\text { Overall- } \\
\text { accept- } \\
\text { ability }\end{array}$ \\
\hline \multirow[t]{4}{*}{ TK } & 0 & $6.1^{\mathrm{a}} \pm 0.05$ & $6.4^{\mathrm{a}} \pm 0.03$ & $6.7^{\mathrm{cd}} \pm 0.04$ & $6.1^{\mathrm{a}} \pm 0.04$ & $6.3^{\mathrm{a}} \pm 0.03$ & $6.1^{\mathrm{a}} \pm 0.05$ & $6.4^{\mathrm{b}} \pm 0.03$ & $6.7^{\mathrm{ab}} \pm 0.04$ & $6.1^{\mathrm{b}} \pm 0.04$ & $6.3^{\mathrm{a}} \pm 0.03$ \\
\hline & 4 & $5.8^{\mathrm{ab}} \pm 0.03$ & $6.3^{\mathrm{ab}} \pm 0.01$ & $6.4^{\mathrm{b}} \pm 0.03$ & $6.3^{\mathrm{a}} \pm 0.03$ & $6.4^{\mathrm{a}} \pm 0.04$ & $6.2^{\mathrm{a}} \pm 0.02$ & $6.4^{\mathrm{b}} \pm 0.02$ & $6.8^{\mathrm{ab}} \pm 0.03$ & $6.0^{\mathrm{ab}} \pm 0.03$ & $6.4^{\mathrm{a}} \pm 0.02$ \\
\hline & 8 & $5.8^{\mathrm{ab}} \pm 0.02$ & $6.1^{\mathrm{ab}} \pm 0.03$ & $5.9^{\mathrm{a}} \pm 0.04$ & $6.0^{\mathrm{ab}} \pm 0.02$ & $6.3^{\mathrm{a}} \pm 0.03$ & $6.0^{\mathrm{a}} \pm 0.03$ & $6.2^{\mathrm{ab}} \pm 0.03$ & $6.5^{\mathrm{a}} \pm 0.02$ & $5.8^{\mathrm{a}} \pm 0.04$ & $6.5^{\mathrm{a}} \pm 0.03$ \\
\hline & 12 & $5.6^{\mathrm{b}} \pm 0.02$ & $6.0^{\mathrm{b}} \pm 0.02$ & $5.6^{\mathrm{a}} \pm 0.02$ & $5.7^{\mathrm{b}} \pm 0.03$ & $5.6^{\mathrm{b}} \pm 0.04$ & $5.9^{\mathrm{a}} \pm 0.04$ & $5.9^{\mathrm{a}} \pm 0.02$ & $6.5^{\mathrm{a}} \pm 0.03$ & $5.7^{\mathrm{ab}} \pm 0.03$ & $5.7^{\mathrm{b}} \pm 0.02$ \\
\hline \multirow[t]{4}{*}{ GFK } & 0 & $7.3^{\mathrm{d}} \pm 0.02$ & $7.0^{\mathrm{cd}} \pm 0.03$ & $7.0^{\mathrm{d}} \pm 0.02$ & $7.4^{\mathrm{d}} \pm 0.02$ & $8.0^{\mathrm{d}} \pm 0.02$ & $7.3^{\mathrm{b}} \pm 0.02$ & $7.3^{\mathrm{d}} \pm 0.02$ & $6.9^{\mathrm{b}} \pm 0.02$ & $7.4^{\mathrm{d}} \pm 0.02$ & $8.0^{\mathrm{d}} \pm 0.02$ \\
\hline & 4 & $7.0^{\mathrm{cd}} \pm 0.04$ & $7.3^{\mathrm{d}} \pm 0.02$ & $6.8^{\mathrm{cd}} \pm 0.03$ & $7.2^{\mathrm{cd}} \pm 0.03$ & $7.6^{\mathrm{cd}} \pm 0.03$ & $7.1^{\mathrm{b}} \pm 0.03$ & $7.2^{c} \pm 0.03$ & $6.7^{\mathrm{ab}} \pm 0.03$ & $7.3^{\mathrm{d}} \pm 0.03$ & $7.5^{\mathrm{c}} \pm 0.03$ \\
\hline & 8 & $6.8^{c} \pm 0.02$ & $6.9^{c} \pm 0.02$ & $6.5^{\mathrm{bc}} \pm 0.02$ & $7.0^{c} \pm 0.02$ & $7.4^{\mathrm{c}} \pm 0.04$ & $7.2^{\mathrm{b}} \pm 0.02$ & $7.2^{c} \pm 0.02$ & $6.8^{\mathrm{ab}} \pm 0.02$ & $7.1^{\mathrm{cd}} \pm 0.02$ & $7.3^{c} \pm 0.04$ \\
\hline & 12 & $6.8^{\mathrm{c}} \pm 0.03$ & $6.7^{\mathrm{c}} \pm 0.03$ & $6.3^{\mathrm{b}} \pm 0.03$ & $7.0^{c} \pm 0.03$ & $7.4^{\mathrm{c}} \pm 0.02$ & $7.0^{\mathrm{b}} \pm 0.03$ & $7.0^{c} \pm 0.03$ & $6.7^{\mathrm{ab}} \pm 0.03$ & $6.9^{c} \pm 0.03$ & $7.6^{\mathrm{cd}} \pm 0.0$ \\
\hline
\end{tabular}

(a) Values are means \pm standard deviations of triplicate determinations

(b) Values not followed by the same superscript on the same column are significantly different (P $\unlhd 0.05$ )

KEY : GFK = Groundnut flour Kilishi

TK = Tunkusa Kilishi (Control)

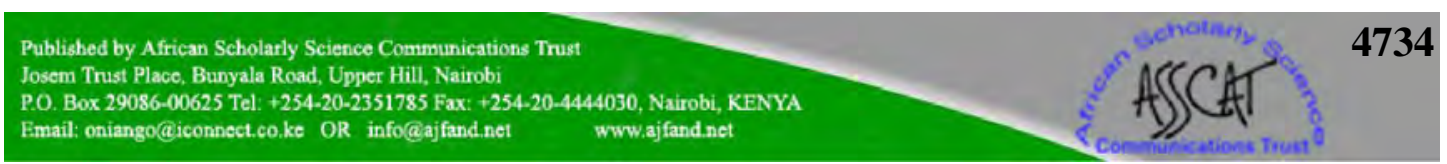




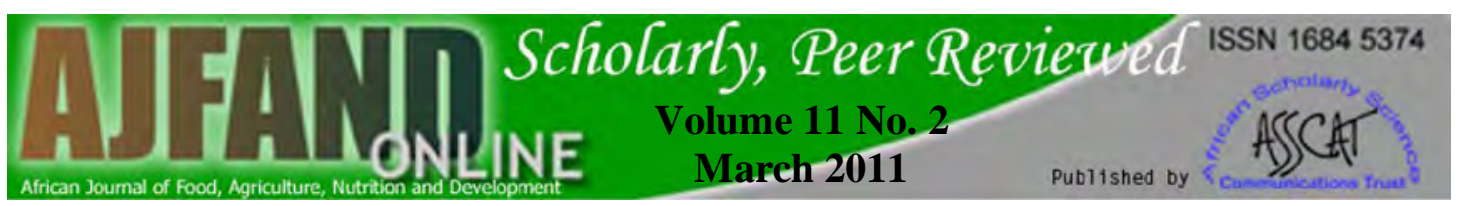

Table 5: Effect of storage at ambient $\left(25-32^{\circ} \mathrm{C}\right)$ and refrigerator $\left(7 \pm 1^{\circ} \mathrm{C}\right)$ temperatures on $\mathrm{pH}$ of (GFK) groundnut flour and (TK) tunkusa kilishi

\begin{tabular}{|c|c|c|c|}
\hline \multirow[b]{2}{*}{ Kilishi Sample } & \multirow[b]{2}{*}{$\begin{array}{c}\text { Storage Period } \\
\text { (W eek) }\end{array}$} & \multicolumn{2}{|c|}{$\mathrm{pH}$ value } \\
\hline & & $\begin{array}{l}\text { A mbient } \\
\left(25-32^{\circ} \mathrm{C}\right)\end{array}$ & $\begin{array}{c}\text { R efrigerator } \\
\left(7 \pm 1^{\circ} \mathrm{C}\right)\end{array}$ \\
\hline \multirow[t]{4}{*}{$\mathrm{TK}$} & 0 & $6.09^{\mathrm{a}} \pm 0.07$ & $6.09^{\mathrm{a}} \pm 0.07$ \\
\hline & 4 & $6.20^{\mathrm{b}} \pm 0.05$ & $6.22^{\mathrm{b}} \pm 0.05$ \\
\hline & 8 & $6.23^{b c} \pm 0.03$ & $6.26^{\mathrm{bc}} \pm 0.04$ \\
\hline & 12 & $6.24^{b c} \pm 0.04$ & $6.28^{\mathrm{c}} \pm 0.03$ \\
\hline \multirow[t]{4}{*}{ GFK } & 0 & $6.18^{\mathrm{b}} \pm 0.04$ & $6.18^{\mathrm{b}} \pm 0.04$ \\
\hline & 4 & $6.21^{\mathrm{b}} \pm 0.03$ & $6.21^{\mathrm{b}} \pm 0.03$ \\
\hline & 8 & $6.25^{b c} \pm 0.03$ & $6.28^{\mathrm{c}} \pm 0.02$ \\
\hline & 12 & $6.28^{\mathrm{c}} \pm 0.02$ & $6.30^{\mathrm{c}} \pm 0.03$ \\
\hline
\end{tabular}

(a) Values are means \pm standard deviations of triplicate determinations

(b) Values not followed by the same superscript on the same column are significantly

different $\quad(\mathrm{P} \unlhd 0.05)$

KEY : GFK = Groundnut flour Kilishi

TK = Tunkusa Kilishi (Control) 


\section{REFERENCES}

1 I gene J O, Farouk M M and CT A kanbi Preliminary studies on the traditional processing of "kilishi"J. Sci. F ood Agric. 1990; 50: 89-98.

$2 \mathrm{McW}$ atters K H Performance of defatted peanut, soybean and field pea meals as extenders in ground beef patties. J. food Sci. 1997; 42 (6): 1492-1494.

3. Woodroof J G Peanuts. In: Desrosier NW (Ed). Bean, Nut and Seed Technology. Elements of Food Technology AVI Pub. CO. Inc. Westport Connecticut. 1977: 193-196.

4 K insella J E Functional properties of proteins in foods: a survey. CRC Critical Reviews in F ood Science and Nutrition 1976; 7: 219-280.

5 Negbenebor CA, Igene J O, M aigoge SP and EK Collison Microbial Quality of "kilishi" Meat Product. J. Anim. Prod. Res. 1990; 10 (2): 91-107.

6 Sexull $A A$ and RL Ory Rapid method for partial hydrolysis of oil seeds proteins for food uses. J ournal of American O il Chemists Society 1977; 54: 3235 .

7 Bhagya S and I Srinivasan Effect of Different Method of Drying on the Functional Properties of Enzyme Treated Groundnut flour. Lebensm-Wiss. U. Technol. 1989; 22: 329-333.

8 Fasina 00 and 00 Ajibola Mechanical expression of oil from conophornut (Tetrarpidium conophorum). J. Agric. Eng. Res. 1989; 44: 275-287.

9 Abubakar UM and PA Sopade Viscosity of Kilishi Slurry at 30 to $70^{\circ} \mathrm{C}$. J. Agric. Sci. Technol. 1994; 4(1): 72-75.

10 Igene J O, Abubakar U, Akanbi T and A Negbenebor Effect of Sodium Tripolyphosphate and Moisture Level on the Drying Characteristics and Yield of Kilishi a sun-dried Beef product. J ournal of Agriculture, Science and Technology, 1993; 3 (2): 166-175.

11 AOAC. "Official Methods of Analysis".16" edn. Association of Official Analytical Chemists. Washington, DC; 1995.

12 Ihekoronye AI and PO Ngoddy Integrated Food Science and Technology for the Tropics $1^{\text {st }}$ edn. Macmillan Pub. Ltd, 1985.

13 Osborn DR and P Voogt The analysis of nutrients in foods. Academic Press London, 1978; 128. 
14 Tarladgis $B G$, Pearson AM and LR Dugan ( $r$ ) Chemistry of the 2thiobarbituric acid (TBA) test for determination of oxidative rancidity in foods 11; formation of the TBA- Malonaldehyde complex with the acid-heat treatment.J .Sci. Food Agric.1964; 15: 602-607.

15 Pearson D "Chemical Analysis of Food. $8^{\text {th }}$ edition. Churchill Living Stone; 1981.

16 Trout GR and GR Schmidt Water binding ability of meat products. Effect of fat level, effective salt concentration and cooking temperature. J. Food Sci., 1984; 51(4): 1061-1062.

17 Harrigan WF and ME MCCance Laboratory methods in Food and dairy microbiology. Suffolk St. Edmunburgh Press U. S.A. 1976.

18 L armond E Laboratory Methods for Sensory Evaluation of Foods. Publication No. 1673. Department of Agriculture, Ottawa, Canada, 1977.

19 Steele RGD and JH Torrie Principles and procedures of statistics $2^{\text {nd }}$ edn. McGraw-Hill Book Co. Inc N.Y., 1980; 185-187.

20 Badau $\mathrm{MH}$, Igene J O, Collison EK and I Nkama Studies on production, physiochemical and sensory properties of a standard Kilishi ingredient mix powder. Int. J ournal of F ood Sci. and Nutri. 1997; 48: 165-168.

$21 \quad M$ bofung CM F The effect of a traditional African method of meat processing on the availability of iron and other minerals from the finished product (Kilishi) following in vitro enzymolysis. In: Schlemer U (Ed) Bioavailability 93. Nutritional, chemical and food processing implication of nutrients availability, proceedings part 2, BFE. 1993; 169-174.

22 Olapade AA, Ugokwe PU, Ozumba AU, Solomon HM, Olatunji O and SO A delaja Physico-chemical properties of premixes for preparation of akara. Nigerian F ood J ournal, 2004; 22: 54-59.

23 I gene J $\mathrm{O}$ and HA Agboola The development of a model pilot production system for improved processing of "kilishi". Commissioning Ceremony of the "Kilishi" model factory project. University Benin, Ekenwan Campus Benin city Nigeria. 2003: 29.

24 Frazier WC and DC W esthoff Food microbiology. $4^{\text {th }}$ edn. New Delhi Tata Mc Graw Hill. Pub coy Ltd. New Delhi, 1988.

25 J ones MJ, Tanya NV, M bofiling DN and DE Silverside A Microbiological and Nutritional Evaluation of the West African dried meat product, "kilishi". The J ournal of food Technology in Africa, 2001; 6 (4): 126-129. 
26 I gene J O Lipid, fatty acid composition and storage stability of kilishi a sun dried meat product. Trop. Sci. 1988; 28: $153-16$.

27 Pearson D Application of Chemical Methods for the Assessment of beef quality part 11- method related to fat spoilage. J Sci. Food Agric.1968b; 19: 553-556.

28 K ranner AC and DD K arel Mechanics of lipid oxidation in meat emulsions. In: Friberg S. (Ed), Food emulsions, Marcel Dekker Inc. NY., 1990; 447.

29 Pearson D The Chemical Analysis of Foods. $7^{\text {th }}$ edition, Churchill Living stone, 1977.

30 ICM SF. International Commission of Microbial Standards for Foods. Microorganisms in Food 2. Sampling for Microbial Analysis. Principles and Specific Applications. Toronto Canada, University Press, 1978; 92. 